(c) American Dairy Science Association, 2005.

\title{
Aerobic Stability of Wheat and Orchardgrass Round-Bale Silages During Winter*
}

\author{
R. T. Rhein, W. K. Coblentz, J. E. Turner,† C. F. Rosenkrans, Jr., \\ R. K. Ogden, and D. W. Kellogg \\ Department of Animal Science, University of Arkansas, Fayetteville 72701
}

\section{ABSTRACT}

Using recently developed technology, balage is often stored in large $(1.2 \times 1.2 \mathrm{~m})$ round bales that are wrapped in plastic film with an in-line wrapper. The aerobic stability of this fermented forage is important, particularly during winter months when it is fed to livestock or sold as a cash crop. Two types of forage, orchardgrass [Dactylis glomerata L.; $54.4 \%$ dry matter (DM)] and wheat (Triticum aestivum L.; $62.4 \%$ DM), were packaged in large round bales and wrapped with an in-line wrapper during May 2002. Twenty-one bales of each balage type were unwrapped and exposed to air on Dec. 10, 2002 for $0,2,4,8,16,24$, or $32 \mathrm{~d}$ (ambient temperature range $=0.6$ to $19.4^{\circ} \mathrm{C}$ ) to evaluate aerobic stability. For both orchardgrass and wheat balage, final bale weight, concentration of $\mathrm{DM}$, and $\mathrm{pH}$ were not affected by exposure time. Across both balage types, DM recoveries were $\geq 97 \%$ for all bales, indicating that both balage types were very stable when exposed to air. For orchardgrass balage, exposure time had no effect on concentrations of NDF, ADF, hemicellulose, cellulose, or lignin, thereby indicating that little deterioration occurred. Similarly, no contrast relating any fiber component with exposure time was significant for wheat balage. Concentrations of crude protein (CP) were not affected by exposure time for wheat balage, but there was a tendency for exposed orchardgrass bales to have greater concentrations of CP than bales sampled on d 0. Exposure time had no effect on 48-h in situ digestibility of DM for wheat balage, but there was a tendency for a linear increase with exposure time for orchardgrass balage. However, the overall range (78.2 to $80.5 \%$ ) over the 32 -d exposure period was very narrow, and this response is probably of limited biological significance. Generally, concentrations of fermentation acids were low, primarily because of the high concentra-

Received August 13, 2004.

Accepted November 19, 2004

Corresponding author: W. K. Coblentz; e-mail: coblentz@uark.edu.

*Contribution of the Arkansas Agricultural Experiment Station.

$\doteqdot$ Current address: North Carolina State University, Mountain Research Station, Waynesville 28786 tion of DM within these balages, and only minimal changes in these acids were observed over the exposure interval. These results suggest that the balage evaluated in this trial during winter conditions was very stable after exposure to air for up to $32 \mathrm{~d}$. This should allow for considerable flexibility with respect to feeding, transport, and marketing of balage during winter months without significant aerobic deterioration.

(Key words: aerobic stability, balage, orchardgrass, round-bale silage)

\section{INTRODUCTION}

In the Upper South, the storage of harvested forages as fermented silage has several advantages over storage as dry hay. A primary advantage is associated with the unstable weather conditions that often occur throughout this region in the spring. Typical weather patterns in April, May, and early June are often rainy with cool temperatures. Normal precipitation levels in Fayetteville, Arkansas, during April, May, and June are 110, 129, and $134 \mathrm{~mm}$, respectively (NOAA, 2002). This increases drying time and makes it very difficult to achieve the level of dehydration necessary for safe storage as dry hay for cool-season annual or perennial grasses, such as wheat, cereal rye (Secale cereale L.), oat (Avena sativa L.), annual ryegrass (Lolium multiflorum Lam.), orchardgrass, or tall fescue (Festuca arundinacea Schreb.). The threshold concentration of DM for satisfactory storage of dry hay is approximately $80 \%$ DM for conventional rectangular bales (Collins et al., 1987), but large round bales are more prone to spontaneous heating (Montgomery et al., 1986) and need to be drier ( 82 to $84 \% \mathrm{DM}$ ) for safe storage. The negative consequences of baling hay before it is dried adequately are widely known to producers; they include molding, spontaneous heating, undesirable changes in forage quality, and potential for spontaneous combustion (Rotz and Muck, 1994; Coblentz et al., 2000; Turner et al., 2002).

As a result of these factors, producers are often faced with the choice of baling hay before it is dried adequately or risking damage to the wilting forage by rainfall events. When rainfall events occur before baling, 
wilting forages suffer losses of plant sugars and other water-soluble nutrients via leaching and/or prolonged or reactivated respiration by plant cells or microbes associated with the forage (Rotz and Muck, 1994). Cellular contents, including plant sugars, are assumed generally to be completely digestible by ruminants (Van Soest, 1982); therefore, the nutritive value of rain-damaged forages is reduced. In contrast, forages harvested as silage need only to be wilted to about $40 \% \mathrm{DM}$, which can be achieved relatively quickly. Therefore, the conservation of forages as silage can preserve plant nutrients and partially avoid dependence on good drying weather.

Historically, precision-chopped forages have been fermented and stored 1) in piles on the ground covered with dirt or plastic, 2) in horizontal trench or bunker silos, 3) in plastic bags or tubes ranging up to $150 \mathrm{~m}$ in length, and 4) in upright silos made of wood, metal, or concrete. Regardless of methodology, a key goal is to reduce respiration by plant cells during filling, and aerobic microbial activity at all points throughout filling, storage, or feed-out (Muck et al., 2003). Indicators of aerobic deterioration that are observed commonly include mold development, spontaneous heating, DM loss, increased concentrations of fiber components, and reduced nutrient digestibilities (Bolsen, 1995). At feedout, aerobic deterioration becomes a critical concern because unlimited oxygen is available to support microbial respiration in all exposed silage. This type of spontaneous heating is dependent on several factors: 1) numbers of aerobic microorganisms in the silage 2) time exposed to oxygen prior to feeding, 3) silage fermentation characteristics, and 4) ambient temperature (Bolsen, 1995).

Recently, an alternative methodology has been developed that allows producers to bale long-stem forages in round bale form and then wrap these bales in a plastic stretch film. This form of storage, often called balage, has become very common in Arkansas and throughout the Upper South, largely because the same equipment can be used for both balage and conventional dry hay. Balage is often stored in long continuous rows of bales that are wrapped in plastic with an automated in-line bale wrapper. This is very convenient and efficient at harvest, but leads to potential problems at feeding because once a long row of balage is opened, oxygen has access to the exposed silage. Aerobic deterioration then can occur if the balage is not fed quickly. Potentially, this can be an even greater problem if the balage is to be sold as a cash crop, because large numbers of bales are exposed simultaneously and then transported prior to feeding. For buyers with a very limited number of animals to feed, exposure times of several weeks following delivery are easily possible. Producers interested in marketing balage as a cash crop often inquire whether balage will remain stable during loading, transport, and subsequent feeding operations at the buyer's facility. The aerobic stability of exposed balage during the winter months, when most of this product is fed or sold, remains unclear. Our objectives were to assess the aerobic stability of orchardgrass and wheat balage exposed to air during December and January in Fayetteville, Arkansas.

\section{MATERIALS AND METHODS}

\section{Forages, Ensiling, and Storage}

On May 6 and 7, 2002, 'Benchmark' orchardgrass and an unstated cultivar of soft-red winter wheat were harvested with a mower conditioner (Model 1411; Ford New Holland, Inc., New Holland, PA) and allowed to wilt to appropriate DM concentrations for ensiling as balage, which were measured as 54.4 and $62.4 \%$ DM, respectively, at the time plastic was removed from the bales. The orchardgrass was harvested at the heading stage of growth, and the wheat was harvested when the seed was at milk stage. Forages were raked into windrows with a New Holland Model 258 side-delivery rake and packaged immediately into $1.2-\times 1.2-\mathrm{m}$ round bales (Model XL604; Vermeer Manufacturing Co., Pella, IA). Bales were removed from the field and wrapped with 6 layers of $0.025-\mathrm{mm}$ thick plastic film (Sunfilm; AEP Industries, Inc., Mt. Top, PA) on an inline bale wrapper (Reeves Manufacturing Ltd., Miscouche, PE, Canada). The bales were positioned in continuous rows on a concrete pad with each row containing only one forage type. Bales remained there, undisturbed, until December 10, 2002; during this time interval, the plastic wrap surrounding the bales was checked regularly for any holes or tears and any potential entry points for air were patched immediately with tape that was resistant to ultraviolet light.

\section{Initial Bale Evaluation}

On December 10, 2002, the plastic wrap covering each row of at least 23 bales of wheat or orchardgrass balage was cut and removed completely from all bales. The bales at the end of each row were discarded, leaving a total of 21 internal bales of each forage type within each row. At exposure (d 0), bales were removed from the concrete pad, weighed, and placed on individual wooden pallets in an open-air pole barn. This method of stacking allowed for air space between bales and ensured equal air exposure across all bales to be evaluated. Bales were not moved with a hay spike; instead, a hydraulic grasping attachment (Model BH100; Vermeer Manufacturing Co.) was used that did not create 
holes or tunnels into the core of the silage bale. Bale width and diameter were measured, and the volume and DM density of each bale were calculated. In addition, bales were sampled with an $0.45-\mathrm{m}$ bale probe (Star Quality Samplers, Edmonton, AB, Canada) to determine the concentration of DM within each bale at the time of exposure. Approximately four to six 0.45-m cores were taken from the center of one side of the bale; these core samples were composited within bale and dried under forced air at $50^{\circ} \mathrm{C}$ to determine $\mathrm{DM}$ concentration. Because these bales were to be evaluated for up to $32 \mathrm{~d}$ after exposure, holes created by the initial core sample were filled with spray foam insulation to prevent air access into the core of the bale. Bales were blocked, based on position in the original wrapped row of orchardgrass or wheat balage, and designated for a second sampling on the opposite side of the bale after $0,2,4,8,16,24$, or $32 \mathrm{~d}$ of exposure.

\section{Temperature Measurements}

Bales designated for exposure for $32 \mathrm{~d}$ were fitted with two thermocouple wires. These wires were positioned $0.15 \mathrm{~m}$ under the bale surface and in the center core of each bale to monitor changes in bale temperature over time. Bale temperatures were taken once daily at $1700 \mathrm{~h}$ with an Omega 450 AKT Type K thermocouple thermometer (Omega Engineering, Stamford, CT) and evaluated for minimum, maximum, and average temperatures over the 32-d exposure period. The ambient air temperature also was obtained at $1700 \mathrm{~h}$ each day using an exposed thermocouple wire that was placed in the storage barn, but was not inserted into a bale or placed in direct sunlight.

\section{Final Bale Evaluation}

Each bale of both forage types was evaluated a second time after $0,2,4,8,16,24$, or $32 \mathrm{~d}$ of exposure. As part of this process, bales were removed from the barn, measured, and weighed. In addition, bales were sampled at 2 depths; these included approximately 15 probes of the bale surface taken to a $0.15-\mathrm{m}$ depth with a core sampler. The bale core was sampled subsequently by inserting a $0.46-\mathrm{m}$ sampling probe into the same holes created by the $0.15-\mathrm{m}$ surface sampling. This procedure avoided any contamination of samples from the bale core with material from the surface layer. A portion of each forage sample was dried under forced air at $50^{\circ} \mathrm{C}$ to determine the final concentration of $\mathrm{DM}$ in the surface layer and core of each bale. The other portion was immediately frozen, stored at $-4^{\circ} \mathrm{C}$, and then used subsequently to determine silage $\mathrm{pH}$ and concentrations of lactate, VFA, and ammonia $\mathrm{N}$ in these silages.
Recoveries of DM for all bales were determined from calculated DM weights of each bale at exposure and after the designated exposure period, where percentage of DM recovery $=[(\mathrm{DM}$ recovered $(\mathrm{kg})$ following exposure)/(initial bale weight $(\mathrm{kg}) \times$ initial concentration of $\mathrm{DM})] \times 100 \%$. The amount of DM recovered following exposure was estimated nondestructively by composite based on the percentages of total bale volume within the $0.15-\mathrm{m}$ surface layer and the bale core and was calculated as DM recovered $(\mathrm{kg})=[$ (weight of bale core $(\mathrm{kg}) \times$ final concentration of DM within the bale core) + (weight of 0.15 -m surface layer $(\mathrm{kg}) \times$ final concentration of DM within the surface layer)]. The nondestructive composite calculation of recovered DM assumed a constant bale density throughout each bale. It should be noted that initial and final determinations of the amount of DM within each bale were made from independent measurements; therefore, DM recovery for 0d bales was not necessarily $100 \%$, and this deviance from complete recovery was largely a result of variation across initial and final determinations of concentrations of DM for each bale. In addition, bales were appraised visually for mold and aerobic deterioration on a scale of 1.0 to 5.0 , where $1.0=$ ideal to $5.0=$ mold and/or other evidence of aerobic deterioration covering the entire outside surface of the bale. Increments of 0.25 were used during this visual evaluation process.

\section{Forage Nutritive Value}

Dry forage samples were ground through a Wiley mill (Arthur H. Thomas, Philadelphia, PA) fitted with either a 1- or 2-mm screen. Portions of each sample ground through a $2-\mathrm{mm}$ screen were stored in sealed plastic bags and retained for subsequent ruminal incubation in situ. Portions of each silage sample ground through a 1-mm screen were analyzed for N, NDF, ADF, hemicellulose, cellulose, and acid detergent lignin. Analysis of NDF and other fiber components were conducted sequentially, using batch procedures outlined by ANKOM Technology Corp. (Fairport, NY) for an ANKOM200 Fiber Analyzer. Neither sodium sulfite or $\alpha$ amylase were included in the NDF solution. Concentrations of $\mathrm{N}$ for each silage sample were determined by combustion methodology (Elementar Americas, Inc., Mt. Laurel, NJ), and CP was calculated by multiplying the percentage of $\mathrm{N}$ in the forage sample by 6.25 .

\section{In Situ Analysis}

Two $508 \pm 14.1-\mathrm{kg}$ ruminally cannulated crossbred (Gelbvieh $\times$ Angus $\times$ Brangus) steers were used to determine the disappearance of DM during a 48-h incubation in situ. The University of Arkansas Institutional Ani- 
mal Care and Use Committee approved surgical procedures, anesthesia for the cannulations, and care of the steers. The steers were housed in individual 3.4- $\times 4.9$ $\mathrm{m}$ pens with concrete floors and offered an alfalfa ( $\mathrm{Med}$ icago sativa L.) hay-based diet at a maintenance level of DMI (2.0\% of BW). On an as-is basis, the ration contained $84 \%$ alfalfa hay $(20.7 \% \mathrm{CP}, 49.2 \% \mathrm{NDF}$, $37.7 \% \mathrm{ADF}$ ) and $16 \%$ corn-based supplement (95.3\% cracked corn, $3.0 \%$ molasses, and 1.7\% trace-mineralized salt). Fresh water was provided ad libitum throughout the trial. The steers were fed equal portions of this diet at 0730 and $1730 \mathrm{~h}$ and adapted to the basal diet for $10 \mathrm{~d}$ prior to initiating the trial.

Duplicate dacron bags $(10 \mathrm{~cm} \times 20 \mathrm{~cm} ; 53 \pm 10 \mu \mathrm{m}$ pore size; ANKOM Technology Corp.) were filled with $5 \mathrm{~g}$ of each dried silage that had been ground previously through a 2-mm screen in a Wiley mill. Dacron bags were heat-sealed using an impulse sealer (Model CD200; National Instrument Co. Inc., Baltimore, MD) and placed in $36-\times 50-\mathrm{cm}$ mesh bags, which were placed in the ventral rumen prior to the $0730 \mathrm{~h}$ feeding and incubated for $48 \mathrm{~h}$. In situ disappearance was calculated as the percentage of forage DM that disappeared from the dacron bags during the 48-h ruminal incubation. Because these in situ analyses included 168 dacron bags ( 2 silage types $\times 21$ bales $\times 2$ sampling depths $\times 2$ duplicates), which is an excessive number to incubate simultaneously in a single steer, one of the duplicate bags containing each dried silage sample was randomly selected to be incubated independently in a second steer. Disappearance values from each steer comprised one of 2 observations for each silage replicate and were therefore averaged across steers prior to conducting any statistical analyses. Following incubation, all dacron bags were subjected to 10 cold-water rinse cycles in a commercial, top-loading washing machine (Model LXR7144EQ1; Whirlpool Corp., Benton Harbor, MI). Rinse cycles consisted of a 1-min agitation and a 2-min spin per rinse cycle (Coblentz et al., 1997; Vanzant et al., 1998). Rinsed dacron bags were dried to a constant weight at $50^{\circ} \mathrm{C}$ and allowed to equilibrate with the air (Vanzant et al., 1996) before analysis for residual DM.

\section{Silage Fermentation Characteristics}

Silage $\mathrm{pH}$ was determined by extracting a 25 -g aliquot of each silage in $100 \mathrm{~mL}$ of distilled water for 2 $h$. The extract was then filtered through 4 layers of cheesecloth, and the $\mathrm{pH}$ was determined with a portable pH meter (Model AP5; Denver Instruments, Arvada, $\mathrm{CO})$. To determine concentrations of VFA and L-lactic acid in silage samples, a 10-g aliquot of each silage was extracted in $45 \mathrm{~mL}$ of a $0.1 \%$ thymol solution at $4^{\circ} \mathrm{C}$ for $7 \mathrm{~d}$. The extract was then filtered through 8 layers of cheesecloth and analyzed for VFA by GLC techniques (Parker, 1981; Supelco, 1975; Supelco, 1990). L-Lactate was determined by reacting lactate with NAD in the presence of lactate dehydrogenase to yield $\mathrm{NADH}$, which was read spectrophotometrically at $340 \mathrm{~nm}$ (Gutmann and Wahlefeld, 1974). Silage ammonia N was quantified by the method of Broderick and Kang (1980).

\section{Statistical Analyses}

Although the orchardgrass and wheat silages were ensiled within a 2-d period, they were not harvested and ensiled for the specific purpose of comparing species. Orchardgrass and wheat forages were ensiled at different stages of growth and at different concentrations of DM. Both of these factors offer great potential to affect nutritional value (Ball et al., 2002), fermentation characteristics (Muck, 1990), or both. Furthermore, initial differences in these characteristics could potentially confound direct comparisons of silage type with specific respect to aerobic stability. For these reasons, silage types were evaluated independently.

Each of the 21 bales of each forage type served as an experimental unit; therefore, there were 3 bales (one per block) assigned to each exposure interval. As described previously, bales were blocked based on their position before the plastic wrap was removed within the original row of silage bales. The final sampling and evaluation for each individual bale was conducted only one time; this exposure interval was preassigned to each bale randomly before the trial was initiated. Therefore, means for each specific exposure time represent the average of 3 replicates (bales). All final physical bale characteristics, such as bale weight, DM recovery, and visual score following exposure were evaluated as a randomized complete block design with exposure time as the treatment term. Single degree-of-freedom contrasts were used to evaluate the effects of exposure time on each response variable. Contrasts included linear, quadratic, and cubic effects of exposure time; in addition, all exposed bales $(2,4,8,16,24$, or $32 \mathrm{~d})$ were compared with bales sampled at exposure (d 0$)$. Initial bale characteristics, such as bale width, diameter, volume, weight, and DM density, were analyzed by the same model; however, analyses were based on predesignated exposure times because all bales were stripped of plastic and evaluated initially for these characteristics on $\mathrm{d} 0$.

For indices of nutritive value, concentrations of fermentation acids, $\mathrm{pH}$, and final concentration of $\mathrm{DM}$, the statistical analysis was expanded to include sampling depth (surface or bale core) as a subplot term. Therefore, these response variables were evaluated in a splitplot design with exposure time as the whole-plot term 
Table 1. Initial physical characteristics of orchardgrass and wheat balage opened on December 10, 2002 and designated for exposure for $0,2,4,8,16,24$, or $32 \mathrm{~d}$. At the time bales were exposed, physical characteristics of each balage type were not affected $(P>0.10)$ by assigned exposure times.

\begin{tabular}{|c|c|c|c|c|c|c|c|}
\hline & $\begin{array}{l}\text { Exposure } \\
\text { time }\end{array}$ & DM & Diameter & Width & Volume & $\begin{array}{l}\text { Weight } \\
\text { (wet) }\end{array}$ & $\begin{array}{l}\text { DM } \\
\text { Density }\end{array}$ \\
\hline & (d) & $(\%)$ & $\longrightarrow(\mathrm{m})$ & - & $\left(\mathrm{m}^{3}\right)$ & $(\mathrm{kg})$ & $\left(\mathrm{kg} \mathrm{DM} / \mathrm{m}^{3}\right)$ \\
\hline \multicolumn{8}{|l|}{ Orchardgrass } \\
\hline & 0 & 51.0 & 1.31 & 1.24 & 1.69 & 674 & 202 \\
\hline & 2 & 53.1 & 1.32 & 1.23 & 1.69 & 713 & 224 \\
\hline & 4 & 58.2 & 1.31 & 1.25 & 1.68 & 677 & 235 \\
\hline & 8 & 54.8 & 1.32 & 1.23 & 1.69 & 668 & 216 \\
\hline & 16 & 51.2 & 1.32 & 1.24 & 1.70 & 698 & 210 \\
\hline & 24 & 56.4 & 1.33 & 1.25 & 1.73 & 698 & 226 \\
\hline & 32 & 56.4 & 1.34 & 1.26 & 1.77 & 671 & 215 \\
\hline & SEM & 4.81 & 0.020 & 0.015 & 0.050 & 17.5 & 14.4 \\
\hline \multicolumn{8}{|l|}{ Wheat } \\
\hline & 0 & 65.8 & 1.37 & 1.24 & 1.84 & 459 & 165 \\
\hline & 2 & 60.0 & 1.39 & 1.23 & 1.88 & 547 & 171 \\
\hline & 4 & 63.5 & 1.38 & 1.25 & 1.89 & 538 & 181 \\
\hline & 8 & 60.9 & 1.39 & 1.24 & 1.87 & 566 & 178 \\
\hline & 16 & 62.0 & 1.37 & 1.24 & 1.82 & 514 & 175 \\
\hline & 24 & 62.8 & 1.37 & 1.23 & 1.81 & 541 & 187 \\
\hline & 32 & 62.1 & 1.37 & 1.24 & 1.84 & 538 & 183 \\
\hline & SEM & 3.89 & 0.013 & 0.015 & 0.046 & 62.2 & 11.9 \\
\hline
\end{tabular}

and sampling depth as the subplot term. The main effect means of exposure time were evaluated by single degree-of-freedom contrasts as described previously. The mean square for the exposure time $\times$ block interaction was used to test these contrasts for significance. Sampling location and the interaction of main effects were tested for significance with the residual error mean square. In all cases, significance was declared at $P=0.05$, and trends were identified at $P=0.10$. For temperature data, thermocouples were placed only in bales that were exposed for the entire 32-d evaluation period; therefore, sampling depth (surface or core) was the only treatment effect evaluated.

\section{RESULTS AND DISCUSSION}

\section{Initial Bale Characteristics}

Within balage type, initial bale characteristics, such as bale diameter, width, volume, weight, and DM density that were measured at the time of exposure to air did not differ $(P>0.10)$ across their preassigned exposure times (Table 1). This verifies that bale characteristics did not differ $(P>0.10)$ at exposure and that any differences observed for these response variables after bales were exposed were not related to characteristics that existed before the bales were unwrapped. This was expected because little biological activity occurs during the stable storage phase in silages unless the anaerobic environment within the silo is compromised (Bolsen, 1995). Generally, orchardgrass and wheat bales had virtually identical measurements of diameter, width, and volume, which also were expected because bale size was pre-set electronically, and each bale was processed, wrapped in plastic, and stored in an identical manner. Although balage types were not compared statistically, the orchardgrass bales were numerically heavier on a wet weight basis than wheat balage (overall means $=686$ and $529 \mathrm{~kg}$ per bale, respectively) when the silage plastic was removed (Table 1). Part of the advantage in weight observed for the orchardgrass balage was associated with DM content; the mean concentration of DM for orchardgrass at exposure was 8.0 percentage units lower than observed for wheat (62.4 vs. $54.4 \%$; Table 1). However, differences in actual bale weight between orchardgrass and wheat bales were not explained entirely on this basis. The DM density of the orchardgrass bales was numerically greater than that observed for wheat bales, ranging from 202 to $235 \mathrm{~kg} / \mathrm{m}^{3}$ compared with a range of only 165 to 187 $\mathrm{kg} / \mathrm{m}^{3}$ for wheat. Many cereal grains, including wheat, have hollow stems, which can result in a bulky forage that is more difficult to pack (Coblentz et al., 2001); however, the range of DM densities for wheat was within the acceptable range $\left(150\right.$ to $\left.190 \mathrm{~kg} / \mathrm{m}^{3}\right)$ for round bale silage reported by Savoie and Jofriet (2003). Potentially, a difference in DM density is an important distinction between bale types; high bale or silage density is known to be effective at reducing the permeability of the silage mass to oxygen, thereby limiting subsequent microbial respiration, elevated internal bale temperatures, and DM loss (Pitt, 1990). 
Table 2. Summary of surface and core bale temperatures for orchardgrass and wheat balage exposed for $32 \mathrm{~d}$.

\begin{tabular}{llll}
\hline Item & $\begin{array}{l}\text { Minimum } \\
\text { temperature }\end{array}$ & $\begin{array}{l}\text { Maximum } \\
\text { temperature }\end{array}$ & $\begin{array}{l}\text { 32-d average } \\
\text { temperature }\end{array}$ \\
\cline { 2 - 3 } & & & \\
Orchardgrass & & & \\
Surface & 3.7 & 10.7 & \\
Core & 2.3 & 14.2 & 6.2 \\
SEM & 0.71 & 1.77 & 7.2 \\
$P$ & $\mathrm{NS}^{1}$ & $\mathrm{NS}$ & 0.11 \\
Wheat & & & 0.023 \\
Surface & 1.9 & 28.0 & \\
Core & 5.2 & 16.4 & 8.7 \\
SEM & 0.33 & 6.5 & 7.8 \\
$P$ & 0.020 & $\mathrm{NS}$ & 1.41 \\
\hline
\end{tabular}

${ }^{1} P>0.10$.

\section{Internal Bale Temperatures}

Generally, elevation of bale temperatures would be expected in bales undergoing aerobic deterioration (Bolsen, 1995; Pitt, 1990); however, there was relatively little temperature response over the 32-d exposure period in any of the bales monitored (Table 2). One specific wheat bale that was monitored for a 32-d exposure period exhibited increased surface and core bale temperatures over time, which increased the overall average bale temperature for wheat after $3 \mathrm{wk}$ of exposure (Figure 1). However, this was the only bale exposed for
$32 \mathrm{~d}$ that exhibited this response. Bale temperatures did fluctuate somewhat with changes in ambient air temperature; however, this clearly would be expected, especially during a December and January exposure period when the ambient air temperatures can be very low. The 30-yr monthly normals for maximum, mean, and minimum ambient temperatures at Fayetteville in December are 7.1, 3.3, and $-2.2^{\circ} \mathrm{C}$; similarly, these respective temperature norms are $6.8,1.3$, and $-4.3^{\circ} \mathrm{C}$ for January (NOAA, 2002).

\section{Final Bale Characteristics}

Final bale weight, DM recovery, and visual mold score were based on whole-bale measurements or evaluations; therefore, sampling location (surface or core) was not part of the treatment structure. In contrast, evaluations of both $\mathrm{pH}$ and the final concentration of $\mathrm{DM}$ in each bale were made at both sampling locations. For orchardgrass, the interaction of main effects did not affect $\mathrm{pH}(P>0.10)$, but there was a weak tendency for this interaction to affect the final concentration of $\mathrm{DM}$ in each bale $(P=0.065)$. The interaction of main effects did not affect either $\mathrm{pH}(P>0.10)$ or the final concentration of DM in each forage $(P>0.10)$ for wheat balage. Because of the limited evidence of interaction, only main effect means are presented and discussed for these 2 response variables.

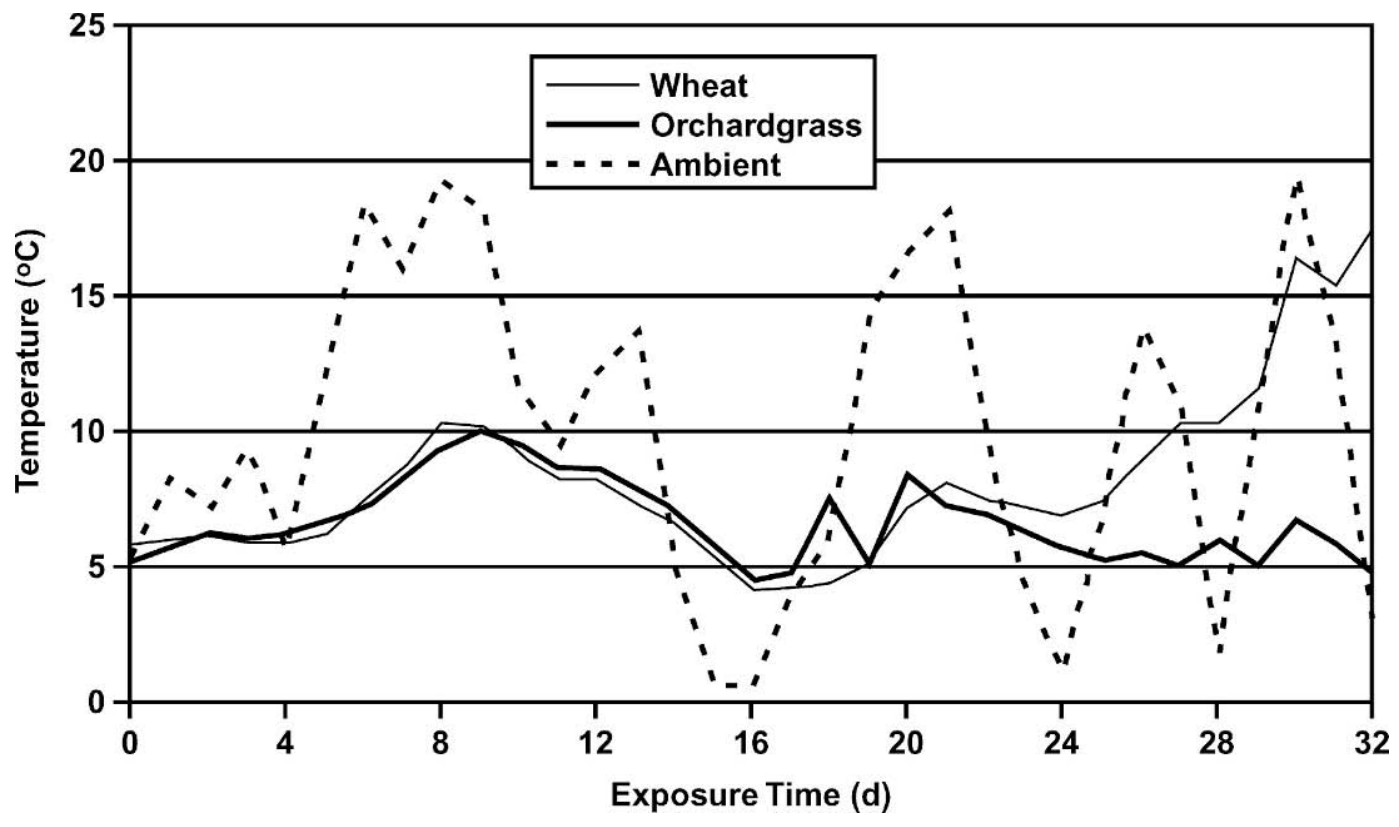

Figure 1. Mean bale temperature versus exposure time for orchardgrass and wheat balages in Fayetteville, Arkansas during December 2002 and January 2003. The response for each balage type is comprised of 3 bales containing thermocouple probes at both a 0.15 -m depth and in the bale core. Ambient air temperatures, measured daily, are shown to illustrate changes in climatic conditions during the 32-d exposure period. 
Table 3. Bale characteristics of orchardgrass and wheat after exposure to air for $0,2,4,8,16,24$, or $32 \mathrm{~d}^{1}$

\begin{tabular}{|c|c|c|c|c|c|c|c|c|c|c|}
\hline \multirow[b]{2}{*}{$\begin{array}{l}\text { Exposure } \\
\text { time }\end{array}$} & \multirow{2}{*}{$\begin{array}{l}\text { Final } \\
\text { bale } \\
\text { weight } \\
\text { (wet) }\end{array}$} & \multicolumn{4}{|c|}{ Orchardgrass } & \multirow{2}{*}{$\begin{array}{l}\text { Final } \\
\text { bale } \\
\text { weight } \\
\text { (wet) }\end{array}$} & \multicolumn{4}{|c|}{ Wheat } \\
\hline & & DM & $\begin{array}{l}\text { DM } \\
\text { Recovery }\end{array}$ & $\mathrm{pH}$ & $\begin{array}{l}\text { Visual } \\
\text { mold } \\
\text { score }^{2}\end{array}$ & & $\mathrm{DM}$ & $\begin{array}{l}\text { DM } \\
\text { Recovery }\end{array}$ & $\mathrm{pH}$ & $\begin{array}{l}\text { Visual } \\
\text { mold } \\
\text { score }^{2}\end{array}$ \\
\hline 0 & 674 & 52.2 & 100.0 & 5.31 & 1.25 & 459 & 64.8 & 99.3 & 5.37 & 1.17 \\
\hline 2 & 711 & 54.1 & 99.7 & 5.12 & 1.17 & 550 & 58.2 & 98.7 & 5.39 & 1.33 \\
\hline 4 & 677 & 59.5 & 100.0 & 5.04 & 1.25 & 532 & 63.8 & 98.3 & 5.41 & 1.42 \\
\hline 24 & 686 & 58.8 & 100.0 & 5.04 & 1.42 & 535 & 65.7 & 100.0 & 5.52 & 1.33 \\
\hline 32 & 647 & 56.9 & 97.3 & 4.84 & 1.08 & 505 & 64.8 & 98.0 & 5.60 & 2.17 \\
\hline SEM & 17.9 & 4.82 & 0.57 & 0.305 & 0.075 & 58.7 & 3.53 & 0.95 & 0.239 & 0.375 \\
\hline \multicolumn{11}{|l|}{ Contrast } \\
\hline Linear $^{3}$ & $\mathrm{NS}^{4}$ & NS & 0.011 & NS & NS & $\mathrm{NS}^{4}$ & NS & NS & NS & NS \\
\hline Quadratic ${ }^{3}$ & NS & NS & 0.036 & NS & NS & NS & NS & NS & NS & NS \\
\hline SEM & $\ldots$ & 0.55 & $\ldots$ & 0.111 & $\ldots$ & $\ldots$ & 0.75 & $\ldots$ & 0.122 & $\ldots$ \\
\hline$P$ & $\ldots$ & NS & $\ldots$ & NS & $\ldots$ & $\ldots$ & 0.0001 & $\ldots$ & NS & $\ldots$ \\
\hline
\end{tabular}

${ }^{1}$ For orchardgrass, the interaction of main effects did not affect $\mathrm{pH}(P=0.268)$; however, there was a weak tendency for this interaction to affect the final concentration of DM in each bale $(P=0.065)$. For the wheat balage, the interaction of main effects did not affect either $\mathrm{pH}(P=0.388)$ or the final concentration of DM in each forage $(P=0.638)$. For these reasons, only main effect means are presented and discussed.

${ }^{2}$ Visual mold score: $1=$ no evidence of mold or aerobic deterioration to $5=$ mold or other evidence of aerobic deterioration covering the entire outside surface of the silage bale.

${ }^{3}$ Linear, quadratic, or cubic effects of exposure time.

${ }^{4} P>0.10$.

${ }^{5}$ Contrast of bales exposed for $2,4,8,16,24$, and $32 \mathrm{~d}$ vs. bales evaluated immediately ( $0 \mathrm{~d}$ ).

Within each individual balage type (Table 3), there were no changes $(P>0.10)$ in bale weight, final concentration of DM, or $\mathrm{pH}$ over the 32-d exposure period. For orchardgrass balage, the final concentration of DM and $\mathrm{pH}$ did not differ $(P>0.10)$ between the bale surface and core; however, the final concentration of DM in the bale core for wheat was 5.5 percentage units greater $(P=0.0001)$ than observed at the bale surface. Although $\mathrm{pH}$ was not affected $(P>0.10)$ by treatment, it was relatively high for both orchardgrass (4.84 to 5.78) and wheat (5.15 to 5.60) at exposure and throughout the trial (Table 3). Annual and perennial cool season grasses are not highly buffered crops (McDonald, 1981); therefore, it is likely that fermentation was restricted following ensiling by the high DM content in both forage types (Jaster, 1995). It is encouraging that there were no effects $(P>0.10)$ of exposure time or sampling location on silage $\mathrm{pH}$ for either balage type. During aerobic deterioration, yeasts, molds, and aerobic bacteria consume plant sugars and fermentation end products, yielding carbon dioxide, water, and heat, and result in elevated silage temperatures and $\mathrm{pH}$ (Pitt, 1990). The relatively wide and somewhat erratic $\mathrm{pH}$ range observed for both balage types can probably be explained more on the basis of bale-to-bale variability in DM concentration at the time of ensiling rather than by aerobic deterioration.

All recoveries of DM following exposure were $\geq 97 \%$ (Table 3), which is near complete recovery and suggests that both balage types were very stable after exposure to air. The linear $(P=0.011)$ and quadratic $(P=0.036)$ decreases in DM recovery observed over the 32-d exposure period for orchardgrass and the cubic $(P=0.034)$ response observed for wheat exhibited very small ranges (97.3 to $100 \%$ and 97.0 to $100 \%$, respectively) and were probably not biologically meaningful. At exposure, some small patches of white mold occasionally were observed over the surface of some bales. This was more common for wheat; however, visual mold scores were very low $(\leq 2.17)$ for all bales of both types, indicating that balage exhibited little evidence of mold or aerobic deterioration at exposure, and little sign of additional deterioration thereafter. No contrast relating visual mold score to exposure time was significant for wheat $(P>0.10)$, but a cubic $(P=0.009)$ response over exposure time was observed for orchardgrass. However, this observation is likely of limited importance because visual mold scores for orchardgrass balage were ex- 
Table 4. Nutritive value of orchardgrass balage after exposure to air for $0,2,4,8,16,24$, or $32 \mathrm{~d}$.

\begin{tabular}{|c|c|c|c|c|c|c|c|}
\hline $\begin{array}{l}\text { Exposure } \\
\text { time }\end{array}$ & $\mathrm{CP}$ & $\mathrm{NDF}$ & $\mathrm{ADF}$ & Hemicelluose & Cellulose & Lignin & $\begin{array}{l}\mathrm{DM} \\
\text { digestion }^{1}\end{array}$ \\
\hline \multicolumn{8}{|c|}{ - $(\%$ of $\mathrm{DM})$} \\
\hline 0 & 12.3 & 65.0 & 37.3 & 27.7 & 32.6 & 3.65 & 78.2 \\
\hline 2 & 13.5 & 65.3 & 36.9 & 28.5 & 32.6 & 3.51 & 78.7 \\
\hline 4 & 13.4 & 67.3 & 37.0 & 30.3 & 32.6 & 3.56 & 77.8 \\
\hline 8 & 13.6 & 67.5 & 37.4 & 30.1 & 32.9 & 3.52 & 78.4 \\
\hline 16 & 14.0 & 67.4 & 38.9 & 28.5 & 33.8 & 4.26 & 77.9 \\
\hline 24 & 14.4 & 65.3 & 36.1 & 29.2 & 31.8 & 3.39 & 80.5 \\
\hline 32 & 13.4 & 66.3 & 37.1 & 29.2 & 32.7 & 3.45 & 79.6 \\
\hline SEM & 0.64 & 1.24 & 0.75 & 1.00 & 0.46 & 0.371 & 0.83 \\
\hline \multicolumn{8}{|l|}{ Contrast } \\
\hline Linear $^{2}$ & $\mathrm{NS}^{3}$ & NS & NS & NS & NS & NS & 0.062 \\
\hline Quadratic $^{2}$ & NS & NS & $\mathrm{NS}$ & NS & NS & NS & NS \\
\hline Cubic $^{2}$ & NS & NS & NS & NS & NS & NS & NS \\
\hline All exposed vs. $0 \mathrm{~d}^{4}$ & 0.058 & NS & NS & NS & NS & NS & NS \\
\hline \multicolumn{8}{|l|}{ Sampling location } \\
\hline Surface & 13.8 & 67.2 & 37.7 & 29.5 & 33.1 & 3.71 & 78.2 \\
\hline Core & 13.2 & 65.5 & 36.8 & 28.7 & 32.4 & 3.53 & 79.2 \\
\hline SEM & 0.24 & 0.30 & 0.21 & 0.14 & 0.19 & 0.074 & 0.31 \\
\hline$P$ & NS & 0.001 & 0.010 & 0.001 & 0.019 & NS & 0.042 \\
\hline
\end{tabular}

${ }^{1}$ Digestibility determined in situ following a 48 -h ruminal incubation.

${ }^{2}$ Linear, quadratic, or cubic effects of exposure time.

${ }^{3} P>0.10$.

${ }^{4}$ Contrast of bales exposed for $2,4,8,16,24$, and $32 \mathrm{~d}$ vs. bales evaluated immediately ( $0 \mathrm{~d}$ ).

tremely low at all exposure times, and the overall range was very narrow (1.08 to 1.42 ; Table 3 ). These observations are encouraging, at least within the context of winter months when temperatures are cool; Savoie and Jofriet (2003) have suggested that little microbiological activity occurs in round bale silage packaged at $<40 \%$ moisture when anaerobic conditions are maintained, but these silages may heat rapidly at retrieval and feeding because higher concentrations of unfermented soluble sugars remain within the silage mass, thereby creating a favorable environment for mold growth. High concentrations of DM, such as those observed for the orchardgrass and wheat balages in the present study $(\geq 52.2 \% \mathrm{DM})$, are often observed to increase susceptibility of silages to heating (Muck et al., 2003); this response occurs, in part, because the specific heat of silage is reduced, resulting a faster rise in silage temperature and concurrent increases in microbial growth rates.

\section{Nutritive Value}

Although not compared statistically, the concentrations of fiber components in the wheat and orchardgrass balages evaluated in this study were quite similar (Tables 4 and 5); for example, respective overall mean concentrations of NDF were 64.0 and $66.3 \%$, and $\mathrm{ADF}$, hemicellulose, cellulose, and lignin also exhibited close agreement across the 2 forage types. In contrast, orchardgrass balage exhibited substantially higher con- centrations of CP than did wheat (overall means $=13.5$ and $7.7 \%$, respectively), but these differences clearly were not related to the silage fermentation process.

Orchardgrass. The interaction of exposure time and sampling location did not affect $(P>0.10$; data not shown) any measure of nutritive value; therefore, only main effects are reported and discussed. Silages that have deteriorated after exposure to air exhibit elevated concentrations of fiber components and reduced energy densities (Pitt, 1990). In this study, exposure time had no effect $(P>0.10)$ on concentrations of NDF, ADF, hemicellulose, cellulose, or lignin in orchardgrass balage, indicating little deterioration occurred. Concentrations of CP tended to be greater $(P=0.058)$ for exposed orchardgrass bales compared with those sampled on d 0 (overall means $=13.8$ and $12.3 \%$ of DM, respectively), while 48-h in situ DM disappearance tended $(P=$ 0.062 ) to increase linearly with exposure time (Table 4). Increased or elevated concentrations of $\mathrm{CP}$ have been reported commonly in harvested forages subjected to undesirable conditions, such as spontaneous heating in hay or silage, rainfall events prior to baling or chopping, or weathering of the surface layer for round bales of hay stored outdoors (Rotz and Muck, 1994). This is likely related to preferential oxidation of nonstructural carbohydrates in association with plant and/or microbial respiration and preferential leaching of these same sugars during rainfall events rather than any additional post-harvest production of forage protein. It re- 
Table 5. Nutritive value of wheat balage after exposure to air for $0,2,4,8,16,24$, or $32 \mathrm{~d}$.

\begin{tabular}{|c|c|c|c|c|c|c|c|}
\hline $\begin{array}{l}\text { Exposure } \\
\text { time }\end{array}$ & $\mathrm{CP}$ & $\mathrm{NDF}$ & $\mathrm{ADF}$ & Hemicelluose & Cellulose & Lignin & $\begin{array}{l}\mathrm{DM} \\
\text { digestion }^{1}\end{array}$ \\
\hline (d) & \multicolumn{7}{|c|}{$\longrightarrow(\%$ of $\mathrm{DM})$} \\
\hline 0 & 8.0 & 66.2 & 37.9 & 28.4 & 32.2 & 3.88 & 73.6 \\
\hline 2 & 7.8 & 63.6 & 38.0 & 25.6 & 33.0 & 4.40 & 76.2 \\
\hline 4 & 7.6 & 64.2 & 37.8 & 26.3 & 33.0 & 4.09 & 75.5 \\
\hline 8 & 7.9 & 62.2 & 36.5 & 25.7 & 31.6 & 4.06 & 76.0 \\
\hline 16 & 7.5 & 65.3 & 37.8 & 27.4 & 33.1 & 3.96 & 74.8 \\
\hline 24 & 7.1 & 61.4 & 36.1 & 25.3 & 31.3 & 3.92 & 76.2 \\
\hline 32 & 7.6 & 64.9 & 39.0 & 25.9 & 33.5 & 4.52 & 75.5 \\
\hline SEM & 0.28 & 2.49 & 1.01 & 2.01 & 0.93 & 0.340 & 1.70 \\
\hline \multicolumn{8}{|l|}{ Contrast } \\
\hline Linear $^{2}$ & $\mathrm{NS}^{3}$ & NS & NS & NS & NS & NS & NS \\
\hline Quadratic $^{2}$ & NS & NS & NS & NS & NS & NS & NS \\
\hline Cubic $^{2}$ & NS & NS & NS & NS & NS & NS & NS \\
\hline All exposed vs. $0 \mathrm{~d}^{4}$ & NS & NS & NS & NS & NS & NS & NS \\
\hline \multicolumn{8}{|l|}{ Sampling location } \\
\hline Surface & 8.0 & 66.2 & 39.0 & 27.3 & 33.9 & 4.27 & 74.1 \\
\hline Core & 7.3 & 61.7 & 36.2 & 25.5 & 31.2 & 3.97 & 76.7 \\
\hline SEM & 0.13 & 0.96 & 0.51 & 0.53 & 0.43 & 0.081 & 0.62 \\
\hline$P$ & 0.003 & 0.005 & 0.002 & 0.035 & 0.001 & 0.022 & 0.010 \\
\hline
\end{tabular}

mains unclear why exposure time would be related positively to 48 -h in situ disappearance of DM; however, the total range of response (78.2 to $80.5 \%$ of $\mathrm{DM}$ ) was very narrow, generally indicating excellent stability following exposure to aerobic conditions rather than a substantial change in digestibility as a result of aerobic exposure.

Unlike exposure time, which had little effect on measures of nutritive value, sampling location affected concentrations of $\mathrm{NDF}(P=0.001), \operatorname{ADF}(P=0.010)$, hemicellulose $(P=0.001)$, cellulose $(P=0.019)$, and 48 -h in situ disappearance of DM $(P=0.042)$. In these cases, concentrations of fiber components were greater at the bale surface than in the bale core; however, the magnitude of these increases was small, ranging from 2.2 to $2.6 \%$ relative to the concentration at the bale core. On a percentage basis, the differential between concentrations of lignin at the bale surface and core was numerically greater than observed for other fiber components (5.1\%), but this response only approached statistical significance $(P=0.11)$. The small elevations in concentrations of fiber components at the bale surface could be explained by losses of volatile compounds to the atmosphere and limited microbial respiration following exposure. In addition, the small increases in concentrations of fiber components at the bale surface likely affected the 48-h in situ disappearance of DM, which was lower $(P=0.042)$ by 1.0 percentage unit at the bale surface compared with the core.
Wheat. As observed for orchardgrass, the interaction of exposure time and sampling location for wheat balage did not affect $(P>0.10$; data not shown) any measure of nutritive value; therefore, only main effects are reported and discussed. No contrast relating any measure of nutritive value with exposure time was significant $(P>0.10$; Table 5) for wheat balage. There was a difference $(P=0.003)$ of 0.7 percentage units for concentrations of CP between sampling locations, with greater concentrations found at the bale surface. Concentrations of NDF $(P=0.005), \mathrm{ADF}(P=0.002)$, hemicellulose $(P=0.035)$, cellulose $(P=0.001)$, and lignin $(P=0.022)$ were greater by 7.1 to $8.7 \%$ at the bale surface than in the bale core; on a percentage basis, these differentials between sampling locations were somewhat larger than observed for the orchardgrass balage. Differences in concentrations of fiber components at the 2 sampling locations also were evident from the assessment of 48h ruminal disappearance of DM; a 2.6 percentage unit advantage $(P=0.010)$ was found in samples taken from the bale core, but the ruminal disappearance for all samples was very high (overall mean $=75.4 \%$ ).

\section{Silage Fermentation Characteristics}

Orchardgrass. The high concentration of DM (51.0 to 56.4\%; Table 1) in the orchardgrass balage likely restricted fermentation and resulted in relatively low concentrations of all fermentation acids and ammonia 
Table 6. Concentrations of VFA and ammonia $\mathrm{N}$ in orchardgrass balage after exposure to air for $0,2,4$, $8,16,24$, or $32 \mathrm{~d}$.

\begin{tabular}{|c|c|c|c|c|c|c|c|}
\hline $\begin{array}{l}\text { Exposure } \\
\text { time }\end{array}$ & $\begin{array}{l}\text { Acetic } \\
\text { acid }\end{array}$ & $\begin{array}{l}\text { Propionic } \\
\text { acid }\end{array}$ & $\begin{array}{l}\text { Isobutyric } \\
\text { acid }\end{array}$ & $\begin{array}{l}\text { Butyric } \\
\text { acid }\end{array}$ & $\begin{array}{l}\text { Lactic } \\
\text { acid }^{1}\end{array}$ & $\begin{array}{l}\text { Ammonia } \\
\mathrm{N}\end{array}$ & $\begin{array}{l}\text { Ammonia } \\
\mathrm{N}\end{array}$ \\
\hline (d) & \multicolumn{6}{|c|}{$\longrightarrow(\%$ of $\mathrm{DM})$} & $(\%$ of $\mathrm{N})$ \\
\hline 0 & 0.73 & 0.06 & 0.026 & 0.33 & 1.20 & 0.015 & 0.73 \\
\hline 2 & 0.69 & 0.02 & 0.003 & 0.04 & 1.03 & 0.014 & 0.65 \\
\hline 4 & 0.38 & 0.01 & 0.001 & 0.01 & 0.72 & 0.013 & 0.59 \\
\hline 8 & 0.37 & 0.03 & 0.004 & 0.10 & 0.73 & 0.014 & 0.67 \\
\hline 16 & 0.41 & 0.06 & 0.028 & 0.23 & 0.74 & 0.029 & 1.26 \\
\hline 24 & 0.29 & 0.02 & 0.005 & 0.10 & 0.63 & 0.019 & 0.82 \\
\hline 32 & 0.36 & 0.01 & 0.002 & 0.04 & 0.72 & 0.014 & 0.65 \\
\hline SEM & 0.082 & 0.023 & 0.0100 & 0.121 & 0.166 & 0.0057 & 0.244 \\
\hline \multicolumn{8}{|l|}{ Contrast } \\
\hline Linear $^{2}$ & 0.004 & NS & NS & NS & 0.064 & NS & NS \\
\hline Quadratic $^{2}$ & 0.028 & NS & NS & NS & NS & NS & NS \\
\hline Cubic $^{2}$ & $\mathrm{NS}^{3}$ & NS & NS & NS & NS & NS & NS \\
\hline All exposed vs. $0 \mathrm{~d}^{4}$ & 0.005 & NS & NS & 0.090 & 0.029 & NS & NS \\
\hline \multicolumn{8}{|l|}{ Sampling location } \\
\hline Surface & 0.51 & 0.04 & 0.013 & 0.13 & 0.81 & 0.021 & 0.93 \\
\hline Core & 0.42 & 0.03 & 0.006 & 0.11 & 0.85 & 0.013 & 0.60 \\
\hline SEM & 0.034 & 0.007 & 0.0035 & 0.031 & 0.042 & 0.0015 & 0.061 \\
\hline$P$ & 0.078 & NS & NS & NS & NS & 0.003 & 0.002 \\
\hline
\end{tabular}

$\mathrm{N}$ at all exposure times (Table 6). This is consistent with observations reported by Muck (1990) for alfalfa silages that suggest that high DM content depresses the rate and total amount of fermentation in silages, resulting in a higher final $\mathrm{pH}$ and lower concentrations of fermentation acids, particularly lactic acid. The interaction of main effects had no effect $(P>0.10$; data not shown) on the concentration of any fermentation acid, but interactions were observed for concentrations of ammonia $\mathrm{N}$ expressed on both a percentage of $\mathrm{DM}(P=$ $0.012)$ and total $\mathrm{N}(P=0.011)$ basis. These interactions were largely the result of a random extreme value for a single bale exposed for $16 \mathrm{~d}$ rather than divergent responses over exposure time at the 2 different sampling locations. For this reason, interactions have been ignored, and only main effects are presented and discussed.

Concentrations of propionic acid, isobutyric acid, and ammonia $\mathrm{N}$ were not affected $(P>0.10)$ by exposure time. Butyric acid concentrations tended $(P=0.090)$ to be lower in exposed bales compared with those evaluated immediately after the plastic wrap was removed on $\mathrm{d} 0$; however, these concentrations were very low (overall mean $=0.12 \%)$ and somewhat erratic $(0.01$ to $0.33 \%$ ) in all bales. Butyric acid is normally associated with undesirable clostridial fermentations that occur most commonly when concentrations of DM are low $(<30 \%$; Bolsen, 1995) at ensiling; therefore, concentrations of butyric acid were expected to be low in these relatively dry silages. Despite the low concentrations $(0.29$ to $0.73 \%)$ of acetic acid in these silages, concentrations declined in linear $(P=0.004)$ and quadratic $(P=$ $0.028)$ patterns with exposure time and were lower $(P=$ 0.005 ) in all exposed bales than those evaluated on $d$ 0 . Similarly, concentrations of lactic acid tended $(P=$ 0.064 ) to decline with exposure time and also were lower $(P=0.029)$ in exposed balage than in bales sampled on d 0. Despite the significant changes in concentrations of both acetic and lactic acids with exposure time, the overall mean concentrations of these acids were very low ( 0.46 and $0.82 \%$, respectively), again reflecting the high DM concentration of this orchardgrass balage. These concentrations are comparable with those $(0$ and $0.6 \%$, respectively) reported by Petit et al. (1993) for mixed grass (mostly timothy; Phleum pratense L.) balage packaged at 54.3\% DM. In contrast, McCormick et al. (1998) reported concentrations of acetic and lactic acids of 3.4 and $5.1 \%$, respectively, in annual ryegrass (Lolium multiflorum L.) balage ensiled at a relatively low concentration of DM (33.5\%).

Sampling location had little effect on the concentration of any fermentation acid. Concentrations of acetic acid tended $(P=0.078)$ to be higher by 0.09 percentage units at the bale surface than in the bale core, but no effect $(P>0.10)$ of sampling location was observed for any other fermentation acid. Concentrations of ammonia $\mathrm{N}$ were lower on both a percentage of $\mathrm{DM}(P=0.003)$ and total N $(P=0.002)$ basis within the bale core than 
Table 7. Concentrations of VFA and ammonia $\mathrm{N}$ in wheat balage after exposure to air for $0,2,4,8,16$, 24 , or $32 \mathrm{~d}$.

\begin{tabular}{|c|c|c|c|c|c|c|c|}
\hline $\begin{array}{l}\text { Exposure } \\
\text { time }\end{array}$ & $\begin{array}{l}\text { Acetic } \\
\text { acid }\end{array}$ & $\begin{array}{l}\text { Propionic } \\
\text { acid }\end{array}$ & $\begin{array}{l}\text { Isobutyric } \\
\text { acid }\end{array}$ & $\begin{array}{l}\text { Butyric } \\
\text { acid }\end{array}$ & $\begin{array}{l}\text { Lactic } \\
\text { acid }^{1,2}\end{array}$ & $\begin{array}{l}\text { Ammonia } \\
\mathrm{N}\end{array}$ & $\begin{array}{l}\text { Ammonia } \\
\mathrm{N}\end{array}$ \\
\hline (d) & \multicolumn{6}{|c|}{$\longrightarrow(\%$ of $\mathrm{DM})$} & $(\%$ of $\mathrm{N})$ \\
\hline 0 & 0.52 & 0.007 & 0.001 & 0.015 & 0.57 & 0.004 & 0.29 \\
\hline 2 & 0.55 & 0.009 & 0.001 & 0.007 & 0.95 & 0.006 & 0.45 \\
\hline 4 & 0.22 & 0.017 & 0.001 & 0.018 & 0.22 & 0.009 & 0.73 \\
\hline 8 & 0.27 & 0.013 & 0.001 & 0.036 & 0.35 & 0.006 & 0.43 \\
\hline 16 & 0.20 & 0.007 & $\mathrm{ND}^{3}$ & 0.006 & 0.25 & 0.003 & 0.25 \\
\hline 24 & 0.15 & 0.003 & 0.001 & 0.001 & 0.22 & 0.015 & 1.17 \\
\hline 32 & 0.14 & 0.005 & 0.001 & ND & 0.22 & 0.011 & 0.87 \\
\hline SEM & 0.093 & 0.0015 & 0.0007 & 0.0118 & 0.137 & 0.0056 & 0.427 \\
\hline \multicolumn{8}{|l|}{ Contrast } \\
\hline Linear $^{4}$ & 0.004 & 0.0004 & NS & NS & 0.011 & NS & NS \\
\hline Quadratic ${ }^{4}$ & $\mathrm{NS}^{5}$ & NS & NS & NS & NS & NS & NS \\
\hline Cubic $^{4}$ & NS & 0.0003 & NS & NS & NS & NS & NS \\
\hline All exposed vs. $0 \mathrm{~d}^{6}$ & 0.022 & NS & NS & NS & NS & NS & NS \\
\hline \multicolumn{8}{|l|}{ Sampling location } \\
\hline Surface & 0.34 & 0.009 & 0.001 & 0.018 & 0.49 & 0.011 & 0.80 \\
\hline Core & 0.24 & 0.007 & ND & 0.006 & 0.30 & 0.005 & 0.40 \\
\hline SEM & 0.044 & 0.0006 & 0.0002 & 0.0035 & 0.015 & 0.0021 & 0.147 \\
\hline$P$ & NS & 0.033 & 0.035 & 0.036 & $<0.0001$ & 0.072 & 0.073 \\
\hline
\end{tabular}

${ }^{1}$ Concentrations of lactic acid exhibited a strong interaction $(P<0.0001)$ between exposure time and sampling location. No such interaction was observed for any other response variable.

${ }^{2}$ L-lactate.

${ }^{3} \mathrm{ND}=$ Not detectable.

${ }^{4}$ Linear, quadratic, or cubic effects of exposure time.

${ }^{5} P>0.10$

${ }^{6}$ Contrast of bales exposed for $2,4,8,16,24$, and $32 \mathrm{~d}$ vs. bales evaluated immediately ( $\left.0 \mathrm{~d}\right)$.

at the bale surface, but the overall mean concentrations of ammonia $\mathrm{N}$ were extremely low $(0.02 \%$ of $\mathrm{DM} ; 0.77 \%$ of $\mathrm{N}$ ), indicating that proteolysis was likely restricted during fermentation.

Wheat. Generally, concentrations of fermentation products and their changes over exposure time (Table 7) followed similar patterns to those observed for orchardgrass balage. The DM content of the wheat balage was 8.0 percentage units lower than that observed for orchardgrass (Table 1), and concentrations of fermentation acids generally were lower in wheat balage than those described for orchardgrass. One notable exception to the general agreement between balage types occurred for lactic acid. Unlike orchardgrass, wheat balage exhibited a strong interaction $(P<0.0001)$ of main effects. Although concentrations of lactic acid did not exceed $1.01 \%$ at either sampling location on any date (data not shown), concentrations of lactic acid declined sharply over exposure time at the bale surface, but remained more stable over exposure time at the bale core. Previously, Gonzalez and Rodriquez (2003) reported decreases in concentrations of lactic acid in balage made from native tropical grasses over a 3-d exposure period at relatively high temperatures.

\section{CONCLUSIONS}

Overall, this experiment demonstrated that wellsealed wheat and orchardgrass balages were very stable for up to $32 \mathrm{~d}$ after exposure to air (ambient temperature range $=0.6$ to $19.4^{\circ} \mathrm{C}$ ), and this could provide considerable flexibility for feeding, transport, and marketing during winter months without significant aerobic deterioration. It is important to emphasize that the exposure period occurred during the winter months when temperatures were low. It should not be inferred that aerobic stability would be the same during other months when temperatures are likely to be substantially warmer.

\section{REFERENCES}

Ball, D. M., C. S. Hoveland, and G. D. Lacefield. 2002. Southern Forages. 3rd ed. Potash and Phosphate Institute and the Foundation for Agronomic Research, Norcross, GA.

Bolsen, K. K. 1995. Silage: Basic principles. Page 163 in Forages, Vol. II, The Science of Grassland Agriculture, 5th ed. R. F. Barnes, D. A. Miller, and C. J. Nelson, ed. Iowa State University Press, Ames.

Broderick, G. A., and J. H. Kang. 1980. Automated simultaneous determination of ammonia and total amino acids in ruminal fluid and in vitro media. J. Dairy Sci. 63:64-75. 
Coblentz, W. K., K. A. Cassida, K. P. Coffey, and L. B. Daniels. 2001. Forage quality characteristics of cereal grain forages and mixtures with annual ryegrass for hay and silage. Fact Sheet \#FSA3063. Arkansas Cooperative Extension Service, Little Rock.

Coblentz, W. K., J. O. Fritz, R. C. Cochran, W. L. Rooney, and K. K. Bolsen. 1997. Protein degradation responses to spontaneous heating in alfalfa hay by in situ and ficin methods. J. Dairy Sci. 80:700-713.

Coblentz, W. K., J. E. Turner, D. A. Scarbrough, K. E. Lesmeister, Z. B. Johnson, D. W. Kellogg, K. P. Coffey, L. J. McBeth, and J. S. Weyers. 2000. Storage characteristics and quality changes in bermudagrass hay as affected by moisture content and density of rectangular bales. Crop Sci. 40:1375-1383.

Collins, M., W. H. Paulson, M. F. Finner, N. A. Jorgensen, and C. R. Keuler. 1987. Moisture and storage effects on dry matter and quality losses of alfalfa in round bales. Trans. ASAE 30:913-917.

Gonzalez, G., and A. A. Rodriguez. 2003. Effect of storage method on fermentation characteristics, aerobic stability, and forage intake of tropical grasses ensiled in round bales. J. Dairy Sci. 86:926-933.

Gutmann, I., and A. H. Wahlefeld. 1974. L (+) lactate determination with lactate dehydrogenase and NAD. Pages 1464-1468 in Methods of Enzymatic Analysis. Vol. 3. H. Bergmeyer, ed. Academic Press, New York, NY.

Jaster, E. H. 1995. Legume and grass silage preservation. Pages 91-115 in Post-Harvest Physiology and Preservation of Forages. CSSA Special Publication No. 22. K. J. Moore and M. A. Peterson, ed. ASA-CSSA-SSSA, Madison, WI.

McCormick, M. E., G. J. Cuomo, and D. C. Blouin. 1998. Annual ryegrass stored as balage, haylage, or hay for lactating dairy cattle. J. Prod. Agric. 11:293-300.

McDonald, P. 1981. The Biochemistry of Silage. John Wiley and Sons, Chichester, UK.

Montgomery, M. J., A. Tineo, B. L. Bledsoe, and H. D. Baxter. 1986. Effect of moisture content at baling on nutritive value of alfalfa orchardgrass hay in conventional and large round bales. J. Dairy Sci. 69:1847-1853.

Muck, R. E. 1990. Dry matter level effects on alfalfa silage quality. II. Fermentation products and starch hydrolysis. Trans. ASAE 33:373-381.

Muck, R. E., L. E. Moser, and R. E. Pitt. 2003. Postharvest factors affecting ensiling. Pages 251-304 in Silage Science and Technol- ogy. D. R. Buxton, R. E. Muck, and J. H. Harrison, ed. ASACSSA-SSSA, Madison, WI.

NOAA. 2002. Monthly station normals of temperature, precipitation, and heating and cooling degree days 1971-2000. Climatography of the United States No. 81. 03 Arkansas. National Climatic Data Center, NESDIS, NOAA, Asheville, NC.

Parker, R. B. 1981. Methodology for Determining Quality of Silage. Natl. Feed Ingredients Assoc., West Des Moines, IA.

Petit, H. V., G. F. Tremblay, P. Savoie, D. Tremblay, J. M. Wauthy. 1993. Milk yield, intake, and blood traits of lactating cows fed grass silage conserved under different harvesting methods. J. Dairy Sci. 76:1365-1374.

Pitt, R. E. 1990. Silage and hay preservation. Cornell Univ. Coop. Ext. Bull. NRAES-5. Northeast Regional Agricultural Engineering Service, Ithaca, NY.

Rotz, C. A., and R. E. Muck. 1994. Changes in forage quality during harvest and storage. Pages 828-868 in Forage Quality, Evaluation, and Utilization. Natl. Conf. Forage Quality, Evaluation, and Utilization, G. C. Fahey, M. Collins, D. R. Mertens, and L. E. Moser, ed. Univ. Nebraska, Lincoln. ASA-CSSA-SSSA, Madison, WI.

Savoie, P., and J. C. Jofriet. 2003. Silage storage. Pages 405-468 in Silage Science and Technology. D. R. Buxton, R. E. Muck, and J. H. Harrison, ed. ASA-CSSA-SSSA, Madison, WI.

Supelco. 1975. GC separation on VFA C2-C5. GC Bulletin749F. Sigma-Alderich Co., St. Louis, MO.

Supelco. 1990. Analyzing fatty acids by packed column gas chromatography. GC Bulletin 856A. Sigma-Alderich Co., St. Louis, MO.

Turner, J. E., W. K. Coblentz, D. A. Scarbrough, K. P. Coffey, D. W. Kellogg, L. J. McBeth, and R. T. Rhein. 2002. Changes in nutritive value of bermudagrass hay during storage. Agron. J. 94:109-117.

Van Soest, P. J. 1982. Nutritional Ecology of the Ruminant. 3rd printing, 1987. Cornell University Press, Ithaca, NY.

Vanzant, E. S., R. C. Cochran, and E. C. Titgemeyer. 1998. Standardization of in situ techniques for ruminant feedstuff evaluation. J. Anim. Sci. 76:2717-2729.

Vanzant, E. S., R. C. Cochran, E. C. Titgemeyer, S. D. Stafford, K. C. Olsen, and G. St. Jean. 1996. In vivo and in situ measurements of forage protein degradation in cattle. J. Anim. Sci. 74:27732784 . 